\title{
Erratum to: Site effect assessment using KiK-net data: Part 1. A simple correction procedure for surface/downhole spectral ratios
}

\author{
Héloïse Cadet • Pierre-Yves Bard • \\ Adrian Rodriguez-Marek
}

Published online: 15 October 2011

(C) Springer Science+Business Media B.V. 2011

\section{Erratum to: Bull Earthquake Eng DOI 10.1007/s10518-011-9283-1}

Unfortunately the name of the first author was captured incorrectly in this article. It should be Héloïse Cadet, not Cadet Héloïse.

The online version of the original article can be found under doi:10.1007/s10518-011-9283-1.

H. Cadet $(\varangle) \cdot$ P.-Y. Bard

ISTerre Institut des Sciences de la Terre, CNRS, University Joseph Fourier, Grenoble, IFSTTAR, BP 53, 38041 Grenoble Cedex 9, France

e-mail: hcadet@obs.ujf-grenoble.fr

H. Cadet

CETE Méditerrannée, Centre d'études Techniquesde l'équipement, Regional Laboratory of Nice, 56 bd Stalingrad, 06359 Nice Cedex 4, France

H. Cadet

ITSAK Institute of Engineering Seismology and Earthquake Engineering, Cosmos Offices 5 Ag. Georgiou Str, Patriarchica Pylaia, 55535 Thessaloniki, Greece

A. Rodriguez-Marek

Charles E. Via Jr. Department of Civil and Environmental Engineering, Virginia Tech, 200 Patton Hall, Blacksburg, VA, 24061, USA 